\title{
Collection time, dehidration, culture media and environment for germination and storage of Campomanesia guazumifolia (Cambess.) O. Berg. pollen
}

\author{
Karina Guollo ${ }^{1}$, Américo Wagner Junior ${ }^{2}$, Carlos Kosera Neto ${ }^{3}$, \\ Juliana Cristina Radaelli ${ }^{3}$, Welida Mayara Tomazoni Keller ${ }^{4}$
}

\begin{abstract}
Sete-capote tree, a neglected species, has great ecological, cultural and potential economic importance, however, studies for this and other native species of the Myrtaceae family are still scarce. The objective of this study was to elucidate aspects of pollen germination and viability of this specie. For the experiment, pollen from flowers in pre and post anthesis was used, which was dehydrated in a chamber containing silica, for different periods. For germination tests, different concentrations of sucrose, boric acid and calcium nitrate were used. After obtaining germination results above $80 \%$, the pollen grains were stored in refrigerator $\left(5^{\circ} \mathrm{C}\right)$, freezer $\left(-17^{\circ} \mathrm{C}\right)$, liquid nitrogen $\left(-147^{\circ} \mathrm{C}\right)$ and natural environment $\left( \pm 25^{\circ} \mathrm{C}\right)$, evaluating monthly the germination, until total loss of viability. For germination, it was recommend using pollen from flowers in post-anthesis, dehydrated for 24 hours in a silica chamber. The culture medium should contain $12 \%$ sucrose $\left(\mathrm{C}_{12} \mathrm{H}_{22} \mathrm{O}_{11}, 10 \%\right.$ boric acid $\left(\mathrm{H}_{3} \mathrm{BO}_{3}\right)$ and $20 \%$ calcium nitrate $\left(\mathrm{Ca}\left(\mathrm{NO}_{3}\right)_{2}\right)$ to obtain high germinative percentages. In addition, pollen presents orthodox behavior and when stored in liquid nitrogen, remains viable for 30 days.
\end{abstract}

Index terms: native fruit tree; culture medium; Myrtaceae; sete-capote tree.

\section{Momento de coleta, desidratação, meio de cultura e ambiente para germinação e armazenamento de pólen de Campomanesia guazumifolia (Cambess.) O. Berg.}

Corresponding author: engkarinaguollo@hotmail.com

Received: August 17, 2020 Accepted: December 15, 2020

Copyright: All the contents of this journal, except where otherwise noted, is licensed under a Creative Commons Attribution License.

\section{(cc) $\mathbf{E Y}$}

Resumo - O sete-capoteiro, espécie negligenciada, apresenta grande importância ecológica e cultural, com grande potencial econômico, todavia, os estudos para essa e demais espécies nativas da família Myrtaceae ainda são escassos. O objetivo deste estudo foi elucidar aspectos da germinação e viabilidade do pólen dessa espécie. Para o experimento, utilizou-se pólen proveniente de flores em pré e pós-antese, o qual foi desidratado em câmara contendo sílica, por diferentes períodos. Para os testes de germinação, utilizaram-se diferentes concentrações de sacarose, de ácido bórico e de nitrato de cálcio. Após obter resultados de germinação acima de $80 \%$, os grãos de pólen foram armazenados em geladeira $\left(5^{\circ} \mathrm{C}\right)$, freezer $\left(-17^{\circ} \mathrm{C}\right)$, nitrogênio líquido $\left(-147^{\circ} \mathrm{C}\right) \mathrm{e}$ ambiente natural $\left( \pm 25^{\circ} \mathrm{C}\right)$, avaliando mensalmente a germinação, até perda total de viabilidade. Para a germinação, recomenda-se a utilização de pólen proveniente de flores em pós-antese, desidratado por 24 horas em câmara de sílica. O meio de cultura deve conter $12 \%$ de sacarose, $10 \%$ de ácido bórico e $20 \%$ de nitrato de cálcio para obtenção de altos percentuais germinativos. Ainda, o pólen apresenta comportamento ortodoxo e, quando armazenado em nitrogênio líquido, permanece viável durante 30 dias.

Termos para indexação: fruteira nativa; meio de cultura; Myrtaceae; sete-capoteiro.

${ }^{1}$ Forestry Engineer, PhD student in Agronomy. Universidade Tecnológica Federal do Paraná - Câmpus Pato Branco, Pato Branco, Paraná, Brazil. E-mail: engkarinaguollo@hotmail.com (ORCID: 0000-0002-5308-3773).

${ }^{2}$ Agronomist Engineer, DSc. Professor, Universidade Tecnológica Federal do Paraná - Câmpus Dois Vizinhos, Dois Vizinhos, Paraná, Brazil. E-mail: americowagner@utfpr.edu.br(ORCID:0000-0001-5081-5281)

${ }^{3}$ Agronomist Engineer, DSc in Agronomy. Universidade Tecnológica Federal do Paraná - Câmpus Pato Branco, Pato Branco, Paraná, Brazil.

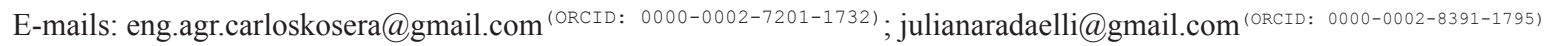

${ }^{4}$ Student of Agronomy, Universidade Tecnológica Federal do Paraná - Câmpus Dois Vizinhos, Paraná, Brazil. welida_sas@hotmail.com ${ }^{(0 R C I D:}$ 00000002-9197-4614) 


\section{Introduction}

The species Campomanesia guazumifolia (Cambess.) native to the Brazilian flora, popularly known as seven-capote tree, belongs to the Myrtaceae family and occurs commonly in the States of Rio de Janeiro, Minas Gerais, São Paulo, Mato Grosso do Sul even Rio Grande do Sul, in almost all groves and forests. In the State of Paraná, it is possible to find the species naturally in the phytophysiognomies of Dense Ombrophilous Forest, Mixed Ombrophilous Forest, Seasonal Semideciduous Forest and steppe (LIMA; GOLDENBERG; SOBRAL, 2011).

It has potential for use in the recovery of degraded areas, composition of permanent preservation areas, ornamentation of urban routes, and because it presents intense flowering and nectar it is beneficial for preserving pollinators and maintaining biodiversity (AQUINO; BARBOSA, 2009; SANQUETTA et al., 2010).

In addition, it has great cultural and potential economic importance. The fruits have the potential to be commercialized, both in natura, as well as juices, jellies, ice cream and other sweets, however, studies that aim at the commercial management of the species to reach a wide scale of commercialization are still scarce. Those that have already been carried out basically comprise the morphological characterization of flowers and fruits (DONADIO; MORO; CUNHA, 2017; LIMA; GOLDENBERG; SOBRAL, 2011; SOUZA; SOUZA; PANOBIANCO, 2018), physicochemical, phytochemical characterization and biological and antimicrobial activities (ARRUDA, 2013; BERNARDO et al., 2015; GOLDONI, 2017), in addition of seed germination (GOLDONI, 2017; SOUZA et al., 2018), and characterization of its essential oil (STEFANELLO et al., 2011).

Aspects related to the flower in the pollination process, such as the viability and germination of pollen grains, are fundamental for the application of management practices and genetic improvement. Reproduction is one of the main pillars to keep the culture economically viable, from an economic point of view, whether through the production of fruits or seeds. Thus, analyzis on reproductive biology are extremely important, both for the natural environment and for production on a commercial scale (SILVA; PINHEIRO, 2007) or for the promotion of new research.

Given the above and the scarcity of research on native species of the Myrtaceae family, the objective of this study was to elucidate aspects of pollen germination and viability of sete-capote tree.

\section{Material and methods}

\section{Study Location}

The study was developed in the Laboratory of Plant Physiology and Orchard of Native Fruit Plants of the UTFPR Experimental Station, Campus Dois Vizinhos - PR, from October to November 2016 and 2017.

\section{Species Used}

The species used were registered in the Universidade Tecnológica Federal do Paraná, Campus Dois Vizinhos (BRASIL. PARANÁ: Dois Vizinhos, Herbário da Universidade Tecnológica Federal do Paraná, 19. IV. 2018, fl., e fr., Guollo, K. 5828 (DVPR)).

\section{Flower Collection and Pollen Desiccation}

Pre and post-anthesis flower and anthers were detached and allotted in paper trays placed in a silica chamber at room temperature $\left( \pm 25^{\circ} \mathrm{C}\right)$, promoting anther dehiscence, release, and desiccation of the pollen grain.

Praparation of Culture Medium

Agar (1\%) was added to the culture medium, which was dissolved in distilled water and heated in a microwave oven until complete dissolution. Still hot, the medium poured into Petri ${ }^{\circledR}$ plates was flow with the help of a spatula after cooling and solidification, forming small blocks that were arranged on slides containing the sprinkled pollen, with the help of a brush no. 4 .

The slides were placed in Gerbox ${ }^{\circledR}$ type boxes with a lid, containing moistened paper (simulated moist chamber) and incubated in oven type B.O.D. (Biological Demand Oxygen $)$ at controlled temperature $\left(25^{\circ} \mathrm{C}\right)$ for 24 hours. For each treatment, eight replicates were used, each block of culture medium in each of the slides representing one replicate.

\section{Experiment 1}

A completely randomized design (CRD) was used in a two-factorial scheme, with factor A corresponding to the origin of the pollen grains (pre- and post-anthesis), factor B corresponding to the desiccation time (0 - control without desiccation; 16 and 24 hours).

\section{Experiment 2}

After obtaining the results of experiment 1 , the concentration of sucrose in the culture medium was evaluate by testing five levels $(0,10,20,30$ and $40 \%)$, using the best conditions in experiment 1 .

\section{Experiment 3}

After obtaining the results of previous experiments, using the ideal condition for collection, desiccation of the pollen grains, and sucrose concentration, the addition of boric acid $(0,2.5,5,7.5$ and $10 \%)$ was tested. 
Experiment 4

Then, by identifying the best results of previous experiments, the addition of calcium $(0,5,10,15$ and $20 \%$ ) was test in the culture medium.

\section{Germination Count}

The number of germinated pollen grains was counted in a binocular microscope, considering only the grains with pollen tube length equal to or greater than the diameter of the pollen grain (FRANZON; RASEIRA, 2006).

\section{Pollen Grain Storage}

After obtaining germination results above $80 \%$, at the end of experiment 4 , the pollen grains were stored in refrigerator $\left(5^{\circ} \mathrm{C}\right)$, freezer $\left(-17^{\circ} \mathrm{C}\right)$, liquid nitrogen $(-147$ $\left.{ }^{\circ} \mathrm{C}\right)$ and natural environment $\left( \pm 25^{\circ} \mathrm{C}\right)$, evaluating monthly the germination, until total loss of viability.
Statistical Analysis

The data were submitted to the normality test (Lilliefors) and homogeneity of variance (Bartllet). The medias of the results were transformed into sine arc of $\sqrt{ } \mathrm{X} / 100$. Given the assumptions of the model, they were submitted to analysis of variance (ANOVA) to verify the significance of the factors and their interactions. When significant, regression analysis was applied to the quantitative factors, using Genes software (CRUZ, 2013).

\section{Results and discussion}

Factors and their interactions were both significant at $5 \%$ error probability level, thus rejecting the null hypothesis $H O$. The germination of pollen grains obtained from post-anthesis flowers was approximately $35 \%$, benefiting from dehydration for 24 hours (Figure 1).

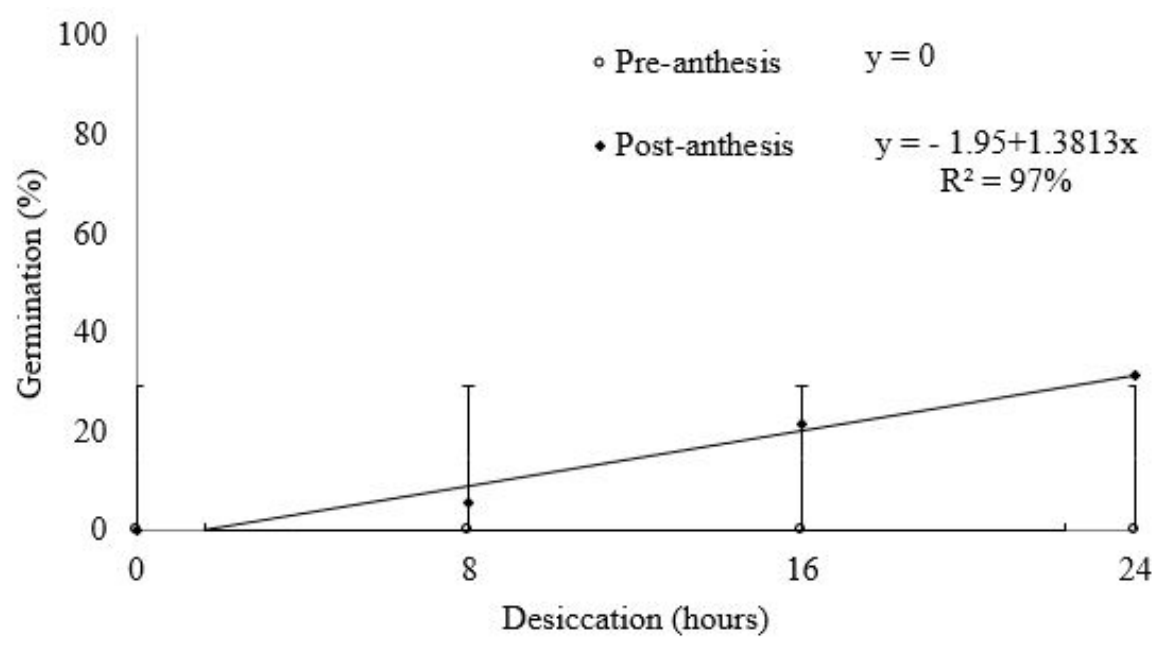

Figure 1. In vitro pollen germination of sete-capote tree as a function of the collection time of flower structures and the desiccation time of the pollen grains.

No germination of pollen grains from preanthesis flowers was observed (Figure 4), as well as in Campomanesia xanthocarpa (Berg.) in a study conducted by Franzon et al. (2006).

Pollen maturation is one of the development stages in the life cycle of plants being primordial in the breeding programs to identify the adequate stage, assuring greater reliability on the hybridization and maintenance of the viability of the pollen grains (FRANZON et al., 2006).

Pollen could also be characterized as recalcitrant (desiccation sensitive) or orthodox (desiccant tolerant) (FRANCHI et al., 2011). The latter was observed in pollen grains of sete-capote tree, which was tolerant to the longest period of desiccation tested.
Recalcitrance behavior was observed in guabiju tree pollen grains, which can be desiccated for a maximum of 2.5 hours and collected in post-anthesis (GUOLLO et al., 2019).

The data obtained for sucrose concentration using pollen of post-anthesis flowers were adjusted to a thirddegree curve. The depletion of the third-degree equation showed that with addition of $12 \%$ sucrose it was possible to reach $29 \%$ of germination (Point of Maximum Technical Efficiency) (Figure 2). 


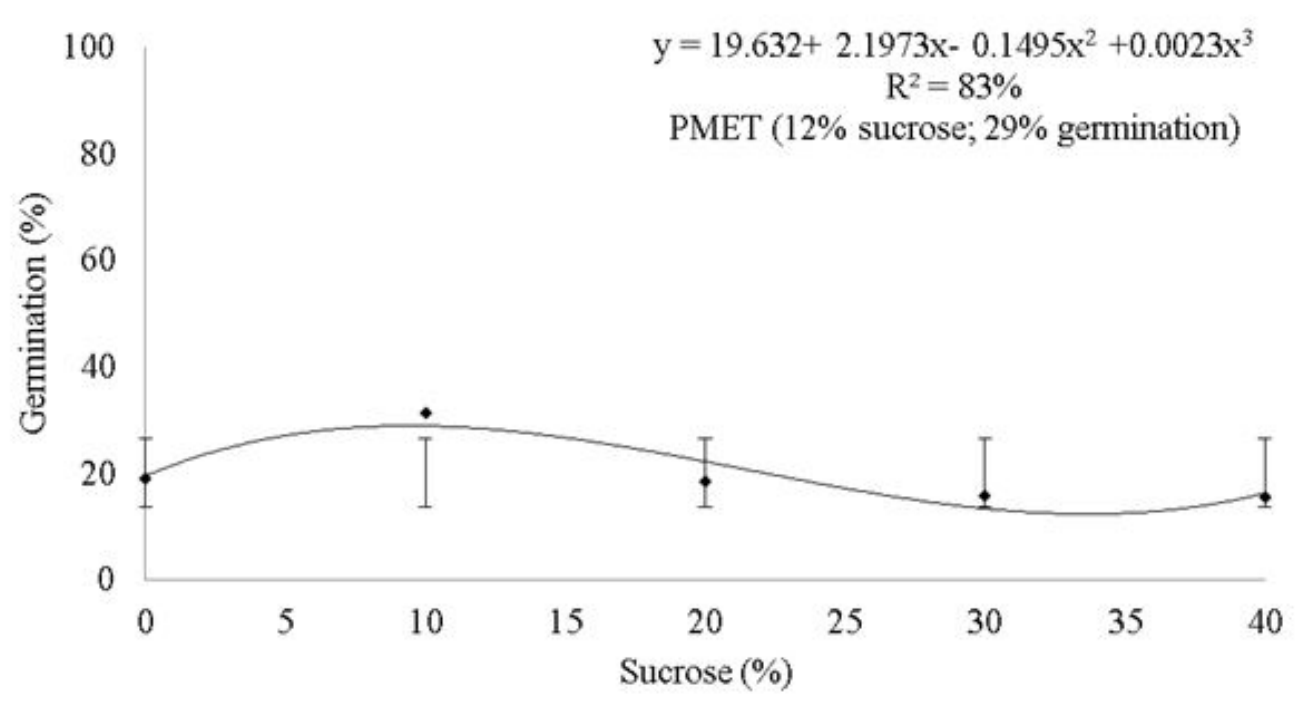

Figure 2. In vitro pollen germination of sete-capote tree as a function of the sucrose concentration in the culture medium.

The adjustment of sucrose concentration for pollen germination is essential because, besides its osmotic role, it also acts in the induction of physiological and metabolic changes, such as the increase of permeability of the pollen tube (Rodriguez-Enriquez et al. 2013), provision of metabolic energy for the biosynthesis of organic compounds, which are primordial for cell growth (CHAGAS et al., 2010; FIGUEIREDO et al., 2013). However, for some species, it must be associated with other nutrients, as well as for sete-capote tree.
Boric acid addition was then evaluated in the culture medium, associated with the best sucrose concentration obtained previously. The addition of $10 \%$ boric acid when using the best sucrose concentration in the previous experiment $(12 \%)$ was efficient to promote the germination of seven-capote pollen grains, reaching approximately $70 \%$ (Figure 3 ).

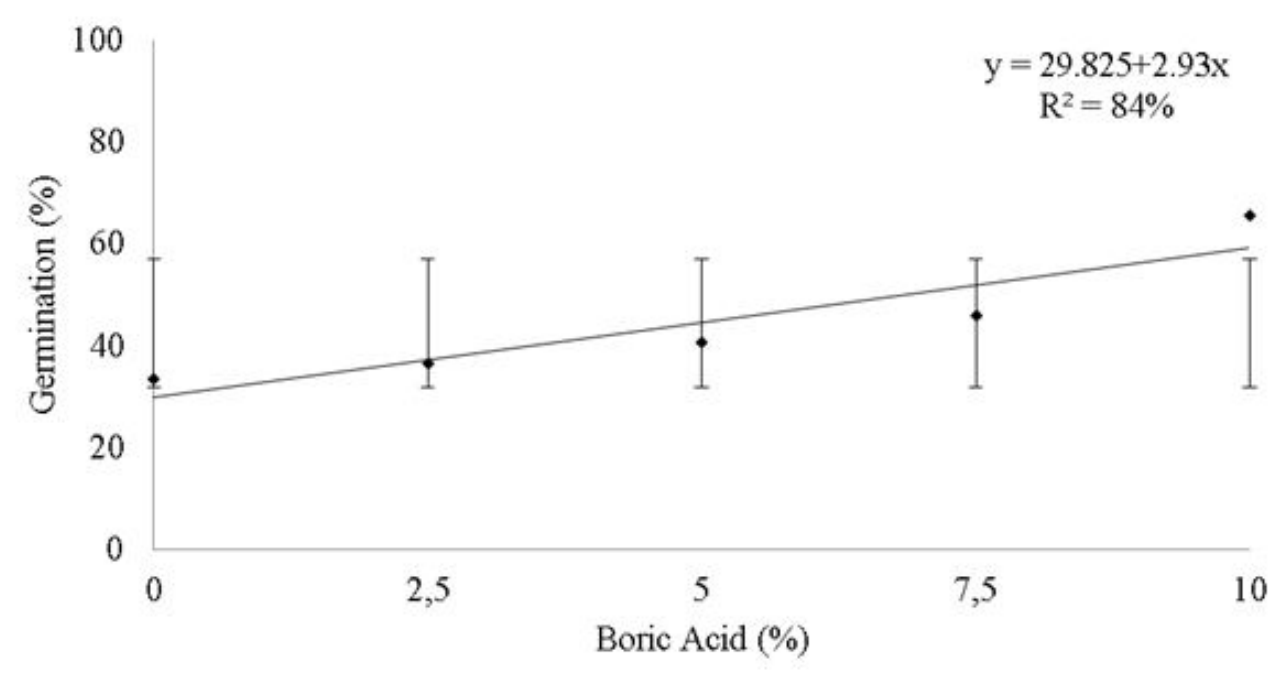

Figure 3. In vitro pollen germination of sete-capote tree as a function of the concentration of boric acid in the culture medium. 
The association of boron and sucrose, ionizable complex form promotes more slightly the development of the pollen tube in vitro (ASKIN et al., 1990). It also stimulates the growth of this one, diminishing the possibility of its rupture, fact that was also observed in studies with different species of fruits (FRANZON; RASEIRA, 2006; CHAGAS et al., 2010; FIGUEIREDO et al., 2013).

In a study realized by Guollo et al. (2019) with 'guabijuzeiro' the use of approximately $10 \%$ of sucrose associated with $7 \%$ of boric acid promoted higher germination percentage of pollen grains when compared to that of seven-capote in this study, reaching approximately $99 \%$.
In order to reach maximum germination percentage, the addition of calcium nitrate to the culture medium was tested, associated with the best conditions previously obtained. The results showed that this addition was beneficial, with increasing linear behavior reaching approximately $95 \%$ of germination with $20 \%$ of calcium nitrate (Figure 4).

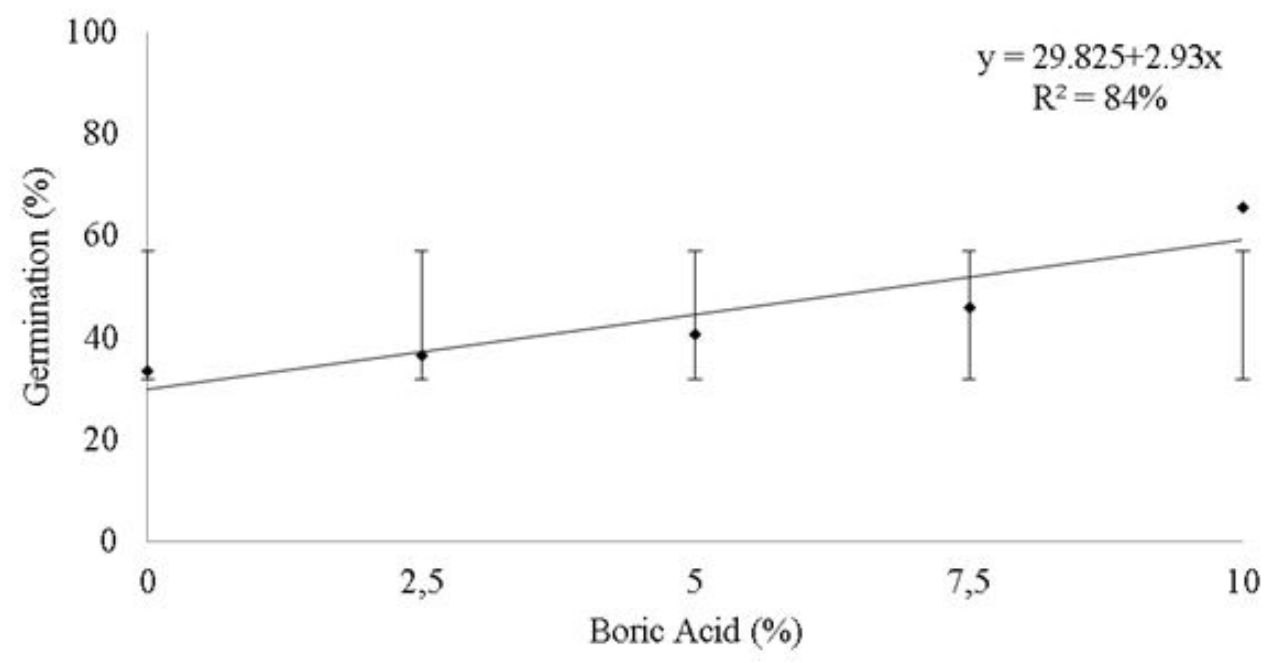

Figure 4. In vitro pollen germination of sete-capote tree as a function of calcium nitrate concentration in the culture medium.

The considerable increase in the germination of pollen grains with the addition of calcium, boron, and sucrose sources to the culture medium is relate to the ability of the species to the need these nutrients.

Ramos et al. (2008) affirmed that the need to add these to the culture medium depends mainly, among other factors of the species (CHAGAS et al., 2010).

Specifically, calcium sources provide favorable physiological conditions, such as increased resistance of the pollen tube and pollen grains, changes in the basic medium, allowing greater impermeability, linear growth and stiffness of the pollen tube (BHOJWANI; BHATNAGAR, 1974), which may have been favorable to the germination of the pollen grains of sete-capote tree.

The pollen grains remained viable only when stores in liquid nitrogen, for up to 30 days, with average germination of only $19 \%$, while for the other evaluated conditions the germination was null.
For future studies, it was recommended that the evaluation should be performed weekly, in view of the viability loss occurring faster in pollen grains because it does not have homeostatic mechanisms to maintain constant water content (FRANCHI et al., 2011).

\section{Conclusion}

For germination, tests of sete capote pollen it is recommended to use pollen from post-anthesis flowers, dehydrated the anthers for 24 hours in a silica chamber. The culture medium should contain $12 \%$ sucrose, $10 \%$ boric acid and $20 \%$ calcium nitrate, to obtain high germination percentages. Still, pollen presents orthodox behavior and when stored in liquid nitrogen, remains viable for 30 days. 


\section{References}

AQUINO, C.; BARBOSA, L.M. Classes sucessionais e síndromes de dispersão de espécies arbóreas e arbustivas existentes em vegetação ciliar remanescente (Conchal, $\mathrm{SP}$ ), como subsídio para avaliar o potencial do fragmento como fonte de propágulos para enriquecimento de áreas revegetadas no rio Mogi-Guaçu, SP. Revista Árvore, Viçosa, v.33, n.2, p.349-358, 2009.

ARRUDA, M.F.C. Estudos morfoanatômico, fitoquímico e de atividades biológicas de Campomanesia guazumifolia (CAMBESS.) O. Berg, Myrtaceae. 95f. Dissertação de Mestrado. Universidade Federal do Paraná. 2013.

BERNARDO, R.; SCHWAN-ESTRADA，K.R.F.; STANGARLIN, J.R.; OLIVEIRA, J.S.B.; CRUZ, M.E.S.; MESQUINI, R.M. Atividade fungitóxica in vitro de extratos vegetais sobre o crescimento micelial de fungos fitopatogênicos. Scientia Agraria Paranaensis, Marechal Cândido Rondon, v.14, n.2, p.89-93, 2015.

BHOJWANI, S.S.; BHATNAGAR, S.P. The embryology of angio-sperms. New Delhi: Skylark, 1974. 264 p.

CHAGAS, E.A.; PIO, R.; CHAGAS, P.C.; PASQUAL, M.; BETTIOL NETO, J.E. Composição de meio de cultura e condições ambientais para germinação de grãos de pólen de porta-enxertos de pereira. Ciência Rural, Santa Maria, v.40, n.2, p.261-266, 2010.

CRUZ, C.D. Programa GENES: aplicativo computacional em genética e estatística (software). Viçosa: Imprensa Universitária, 2013. 442p.

DONADIO, L.C.; MORO, F.; CUNHA, E.L. Frutíferas Nativas e Exóticas: Morfologia Floral. UNESP: Jaboticabal, 2017. 324p.

FIGUEIREDO, M.A.; PIO, R.; SILVA, T.C.; SILVA, K.N. Características florais e carpométricas e germinação in vitro de grãos de pólen de cultivares de amoreira-preta. Pesquisa Agropecuária Brasileira, Brasília, DF, v.48, n.7, p.731-740, 2013.

FRANCHI, G.G.; PIOTTO, B.N.; NEPI, M.; BASKIN, C.C.; BASKIN, J.M.; PACINI, E. Pollen and seed desiccation tolerance in relation to degree of developmental arrest, dispersal and survival. Journal of Experimental Botany, Oxford, v.62, p.5267-5281, 2011.
FRANZON, R.C.; RASEIRA, M.C.B. Germinação in vitro e armazenamento do pólen de Eugenia involucrata DC (Myrtaceae). Revista Brasileira de Fruticultura, Jaboticabal, v.28, n.1, p.18-20, 2006.

FRANZON, R.C; RASEIRA, M.C.B; WAGNER JUNIOR, A. Germinação in vitro de pólen de guabirobeira (Campomanesia xanthocarpa BERG). Revista Ceres, Viçosa, MG, v.53, n.305, p.129-134, 2006.

GOLDONI, J. Caracterização físico-química, atividade antimicrobiana de frutos e germinação de sete capoteira [Campomanesia guazumifolia (CAMBESS.) O. BERG]. 83f. Dissertação de Mestrado. Universidade Federal da Fronteira Sul. 2013.

GUOLLO, K.; AMERICO, WAGNER JUNIOR; DALLAGO, A.; VODZINSKI, R.S.; RADAELLI, J.C. Floral, reproductive and pollinator biology Myrcianthes pungens (Berg) Legrand, neglected species. Acta Scientiarum, Maringá, v.41, p.2-12, 2019.

LIMA, D.F.; GOLDENBERG, R.; SOBRAL, M. O gênero Campomanesia (Myrtaceae) no estado do Paraná, Brasil. Rodriguésia, Rio de Janeiro, v.62, n.1, p.683-693, 2011.

RAMOS, J.D.R.; PASQUAL, M.; SALLES, L.A.; CHAGAS, E.A.; PIO, R. Receptividade do estigma e ajuste de protocolo para germinação in vitro de grãos de pólen de citros. Interciência, Santiago, v.33, n.1, p.51$55,2008$.

RODRIGUEZ-ENRIQUEZ, M.J.; MEHDI, S.; DICKINSON, H.G.; GRANT-DOWNTON, H.T. A novel method for efficient in vitro germination and tube growth of Arabidopsis thaliana pollen. New Phytologist, London, v.197, p.668-679, 2013.

SANQUETTA, C.R.; FERNANDES, L.A.V.; MIRANDA, D.L.C.; MOGNON, F. Inventário de plantas fornecedoras de produtos não madeireiros da floresta ombrófila mista no Estado do Paraná. Scientia Agraria, Curitiba, v.11, n.1, p.359-369, 2010.

SOUZA, M.T.; SOUZA, M.T.; PANOBIANCO, M. Morphological characterization of fruit, seed and seedling, and seed germination test of Campomanesia guazumifolia. Journal of Seed Science, Londrina, v.40, n.1, p.000-000, 2018.

STEFANELLO, M.E.A.; PASCOAL, A.C.R.F.; SALVADOR, M.J. Review - Essential oils from neotropical Myrtaceae: chemical diversity and biological properties. Chemistry and Biodiversity, v.8, n.1, p.7394, 2011. 